3. Anderson L. A taxonomy for learning, teaching and assessing. New-York: Longman, 2001. 336 p.

4. Bloom B. Taxonomy of educational objectives: The classification of educational goals. New-York: Longman, 1984. 207 p.

5. Thorndike R., Hagen E. Measurement at evaluation in psychology and education. New-York: Wiley; London: Chapman and Hall, 1955. P. 5-23.

DOI https://doi.org/10.30525/978-9934-26-073-5-2-71

\title{
ЛІНГВООРІЄНТОВАНА МЕТОДИКА У ВИКЛАДАННІ УКРАЇНСЬКОЇ МОВИ ЯК ІНОЗЕМНОЇ
}

\author{
Підгородецька І. Ю. \\ кандидат філологічних наук, дочент, \\ доиент кафедри мовних дисииплін \\ Харківського начіонального аграрного університету \\ імені В. В. Докучаєва \\ Тихоненко О. В. \\ кандидат філологічних наук, доцент, \\ дочент кафедри мовних дисииллін \\ Харківського начіонального аграрного університету \\ імені В. В. Докучаєва
}

Баласанян О. Д. старший викладач кафедри іноземних мов і міжкультурної комунікаиії Харківського національного економічного університету імені Семена Кузнеия м. Харків, Украӥна

У перші десятиліття XXI ст. глобалізаційні процеси охопили всі сфери суспільного життя, зокрема й галузь освіти. Інтеграція українських ЗВО в європейський освітній простір, навчання іноземних здобувачів із пострадянських країн, Африки та Азії у вишах України вимагають нових підходів до викладання української мови як мови навчання і державної мови України [3, с. 167]. Крім того, інтернаціоналізація освіти дає можливості здобувати знання в умовах міжкультурної взаємодії, що висуває нові вимоги до стандартів освіти, зокрема оволодіння мовою 
держави на тому рівні, який дозволить ефективно співпрацювати 3 представниками інших національностей [4, с. 202].

Вивчення української мови $є$ обов'язковим для всіх іноземних студентів, які здобувають вищу освіту у ЗВО України. На підготовчих факультетах українська мова $\epsilon$ i навчальною дисципліною, i засобом опанування інших предметів, передбачених стандартом з української мови як іноземної, що регулює організацію навчання іноземців української мови на підготовчому відділенні й основних курсах (укладачі Н. Ніколаєва, Н. Бондарєва, А. Дем'янюк, М. Шевченко, В. Овдіюк, М. Якубовська) загалом і навчальною програмою зокрема.

В останні роки з'явилася низка праць, присвячених різним аспектам викладання української мови як іноземної. Так, наприклад, науковці розглядають проблеми формування орфоепічних умінь (Н. Василенко), граматичних навичок (З. Мацюк, Л. Паламар, Н. Станкевич), подолання фонетичної інтерференції (Т. Кірик), методики викладання української мови як іноземної в умовах білінгвізму (О. Колтунов, О. Сікорська, Т. Оладько), формування лексичної, лінгвокраїнознавчої, міжкультурної та комунікативної компетентностей іноземних студентів (Т. Кудіна, I. Підгородецька, О. Тихоненко). Однак питання лінгвоорієнтованої методики навчання української мови як іноземної залишаються поза увагою вітчизняних дослідників, що й визначає актуальність цієї розвідки. Методика цільового навчання мови, орієнтована на певний мовний контингент учнів, має різні визначення в наукових дослідженнях з лінгводидактики: порівняльна, контрастивна, конфронтативна, лінгвоорієнтована [1].

Власний досвід практичної роботи 3 викладання мов засвідчує значний вплив рідної мови іноземних учнів на процес засвоєння ними української мови. Кожен індивід як носій певної лінгво- та етнокультури сприймає чужу мовно-культурну реальність на основі зіставлення зі своєю мовою і культурою. Викладач має враховувати чинник рідної мови іноземних учнів, навчаючи їх української мови, і залежно від етнічної приналежності студентів використовувати лінгвоорієнтовані підходи та методи.

Мета дослідження - на основі досвіду викладання української мови в арабомовних групах виявити труднощі сприйняття української мови іноземними студентами й запропонувати шляхи їх розв'язання.

Існує два види впливу рідної мови на вивчення іноземної: перенесення (транспозиція) та інтерференція - позитивний і негативний вплив рідної мови відповідно. Транспозиція полегшує засвоєння учнями явищ чужої мови за аналогією 3 подібними явищами рідної мови. 
Інтерференція, навпаки, заважає вивченню іноземної мови, призводячи до змішування мовних понять і помилок. Українська та арабська мови належать до різних мовних груп (слов'янської і семітської відповідно) і навіть до різних сімей (індоєвропейської та афразійської), через що інтерференція домінує над транспозицією під час вивчення однієї з цих мов носіями іншої.

Педагогові варто знати, які труднощі у вивченні української мови можуть спіткати іноземних учнів на різних етапах навчання залежно від їхньої мовної приналежності. Студенти, чиєю рідною мовою $є$ арабська, вже на фонетичному етапі стикаються з проблемами вимови, розрізнення звуків на слух, написання літер. Слід зауважити, що в арабській мові $\epsilon$ тільки три голосні фонеми (довгі і короткі), які частково відповідають голосним звукам української мови $-a, i$ та $y$. Арабський консонантизм має 5 пар, протиставлених за дзвінкістю-глухістю, а в українській мові налічуємо 11 пар; в арабській мові немає звуку в. Крім того, в арабській мові існують емфатичні (вимовляються з особливим напруженням) дуже тверді приголосні, що характеризуються низьким горловим тембром $(m, \partial, c, 3)$. Приголосний звук в арабській мові може бути твердим або м'яким [2]. Тому на практичних заняттях важливо ретельно відпрацьовувати вимову твердих і м'яких приголосних $\partial, m, c$, з; звертати увагу іноземних учнів на розрізнення фонем $\sigma, n$ (оскільки в арабській мові немає звука $n$ і студенти можуть замінювати його звуком б); на правильне вимовляння звука в; навчити артикуляції шиплячих звуків; слідкувати за чіткою диференціацією голосних (підкреслити, що звук $a$ в наголошеній та в ненаголошеній позиції вимовляємо як $a$; звук $y$ більш лабіалізований, тому його не треба наближати до звука $o$ ).

Фонетичні вправи, складені з урахуванням наведених вище особливостей арабського вокалізму й консонантизму, дадуть можливість сформувати в іноземних учнів фонематичний слух, допоможуть засвоєнню ними основних артикуляційних і акустичних характеристик звуків української мови, насамперед тих, що значно відрізняються від подібних звуків їхньої рідної мови або повністю відсутні у фонетичній системі арабської мови.

Не менш важливим на перших заняттях $є$ навчання іноземних учнів української графіки, формування в них навичок кириличного письма, встановлення відповідності між звуками і буквами. Як зазначають науковці, арабомовні студенти допускають багато помилок у написанні голосних, тому що в арабському письмі позначаються тільки приголосні звуки; окрім того, у ньому немає великих літер і відсутня різниця в 
друкованому та письмовому варіантах написання букв [2]. Звичайно ж, викликає труднощі й манера письма зліва направо.

Система 3 семи відмінків в українській мові також представляє значні труднощі для арабських учнів, оскільки в граматичній системі арабської мови тільки три відмінки: називний, родовий і знахідний. Це викликає розбіжності дієслівного керування, відмінності в розподілі відмінкових значень. Основна функція називного відмінка в обох мовах - вираження суб'єкта. Однак в арабській мові підмет може бути і в знахідному відмінку (після певних часток, модальних слів, дієслів-зв'язок тощо). Родовий відмінок в арабській мові містить широкий спектр значень, що відповідають родовому, давальному, орудному і місцевому відмінкам української мови. Так, родовий відмінок без прийменника в деяких функціях (наприклад, приналежності - книга брата) збігається у двох мовах. А у функції призначення предмета арабському родовому відмінку відповідають інші синтаксичні конструкції в українській мові (наприклад, шафа для книг, щзітка для зубів - дослівно арабською шафа книг, щітка зубів). Родовий відмінок із прийменниками фi (в) і ала (на) відповідає українському місцевому відмінку зі значенням місця. Однак семантика цих прийменників не ідентична, що призводить до частих помилок арабських студентів, пов'язаних зі змішуванням цих прийменників (в моїй батьківщзині, в факультеті) [2].

Категорії роду і числа іменників та прикметників в українській та арабській мовах також відрізняються. В арабській мові ширше представлена категорія числа (крім однини і множини є подвійне число). Проте в українській мові $є$ середній рід, що не має аналогів в арабській мові і засвоєння якого вимагає особливої уваги викладачів і студентів.

Труднощі, пов'язані з уживанням лексики, можна класифікувати таким чином: складність запам'ятовування слів і виразів; часткові й повні словникові лакуни; лексична сполучуваність.

Отже, застосування лінгвоорієнтованої методики у викладанні української мови як іноземної передбачає знання викладачем основних відмінностей між українською мовою та рідною мовою студентів та застосування особливих методів і прийомів попередження лексикограматичних помилок шляхом підбору вправ і завдань, складених на основі зіставлення двох мов, на всіх етапах навчання іноземних студентів.

\section{Література:}

1. Вагнер В. Н. Лингвоориентированная методика преподавания русского языка как иностранного. Традиции и новации в 
профессиональной деятельности преподавателя русского языка как иностранного: учеб. монография / под общ. ред. С. А. Хаврониной, Т. М. Балыхиной. Москва, 2002. С. 60-74.

2. Зайдия С. О преподавании русского языка в Дамасском университете. Русский язык за рубежом. 2001. № 2. С. 58-61.

3. Підгородецька І. Ю. Лінгводидактичний підхід у викладанні української (російської) мов як іноземних. Інновації та традииї у мовній nідготовиі студентів: тези доп. Міжнар. наук.-практ. семінару (Харків, 8 грудня 2020 р.). Харків: ХНУБА, 2020.С. 167-169.

4. Тихоненко О. В. Формування лінгвокраїнознавчої, міжкультурної та комунікативної компетентностей у навчанні української мови як іноземної. Інноваиії та традииії у мовній підготовичі студентів: тези доп. Міжнар. наук.-практ. семінару (Харків, 8 грудня 2020 р.). Харків: ХНУБА, 2020. С. 202-205.

DOI https://doi.org/10.30525/978-9934-26-073-5-2-72

\title{
МЕТОДИ НА ЗАНЯТТЯХ 3 ПЕРЕКЛАДОЗНАВСТВА
}

\author{
Самаріна B. B. \\ кандидат філологічних наук, доиент, \\ доцент кафедри ділової іноземної мови та перекладу \\ Національного технічного університету \\ «Харківський політехнічний інститут» \\ Бадан А. А. \\ кандидат філологічних наук, професор \\ завідувач кафедри ділової іноземної мови та перекладу \\ Національного технічного університету \\ «Харківський політехнічний інститут» \\ м. Харків, Украӥна
}

Під час перекладу перекладач знаходиться у процесі пошуку схожих рис між мовами та культурами. Але переклад не може і не повинен бути спрямованим на усунення цих розбіжностей; переклад має зберігати відмінності, певну чужість оригіналу, нагадувати читачу про надбання та втрати процесу перекладу та про відстань між культурами [3, с. 202].

Підкреслюючи роль роботи з інформацією при здійсненні перекладу, вчені надають ій провідну роль у процесі перекладу. У зв'язку із 264 